\title{
慢性硬膜下血腫の非観血的療法
}

\author{
CT 所見の経時的変化，特に delayed contrast enhancement GT 所見につい \\ $\tau$
}

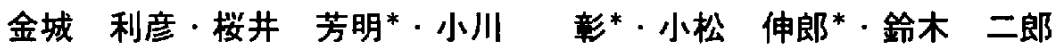

\section{Nonsurgical Treatment of Chronic Subdural Hematoma}

\author{
Sequential Changes of Computed Tomography Findings
}

\author{
Toshihiko KInJo, Yoshiharu Sakurai*, Akira OGawa*, Shinro Komatsu* \\ and Jiro SuzukI
}

Division of Neurosurgery, Institute of Brain Diseases, Tohoku University, Sendai; *Stroke Center, Sendai National Hospital, Sendai

\begin{abstract}
Sequential changes of clinical symptoms and computed tomography (CT) scans were investigated in 20 patients of chronic subdural hematoma treated by osmotherapy utilizing intravenous $20 \%$ mannitol $1,000 \mathrm{~m} l$ daily for 2 weeks. Plain, contrast enhancement, and 4-hour-delayed contrast enhancement CT scans were taken once every week for 4 weeks from the start of the treatment and then once every month until hematoma disappeared. Though the clinical symptoms aggravated slightly in 4 cases during the first or second week, all the cases became asymptomatic at the end of the treatment and showed no recurrence thereafter. Sequential changes in CT scans are summarized as follows. 1) Plain CT scans showed that the hematoma started to reduce in size rapidly after termination of the treatment. Density of hematoma decreased sequentially, although it increased transiently in 9 cases. After treatment, the hematoma disappeared after 3 months in 18 cases, after 4 months in one case, and 5 months in one case. 2) In contrast enhancement CT, two types of contrast enhancement were observed: ribbon-like cortical enhancement and linear enhancement beneath the hematoma. These enhancement effects were seen in $80 \%$ of cases (cortical enhancement in $70 \%$, linear enhancement in $10 \%$ ) before the treatment. The cortical enhancement decreased through the treatment and disappeared in 2 months after the treatment. 3) The contrast enhancement effects within the hematoma cavity (evaluated as the relative increase of the CT numbers in the 4-hour-delayed contrast enhancement CT scans) were closely related to the hematoma reduction rate; the more marked and lasting the enhancement effects, the more delayed was the hematoma to be reduced by osmotherapy. These results may support the authors' previous view, based on an electronmicroscopic study, that the permeability in the sinusoidal channel layers of the outer membrane of the hematoma increases in the active and growing stage and gradually normalizes in the healing stage. The delayed contrast enhancement study is thought to be useful in evaluating the activity of chronic subdural hematoma.
\end{abstract}

Key words: subdural hematoma, osmotherapy, computed tomography, contrast enhancement

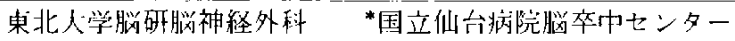

Address reprint requests to: T. Kinjo, M.D., Division of Neurosurgery, Institute of Brain Diseases, Tohoku University, 1-1 Seiryo-cho, Sendai 980 .

受稿 1984尔5月 月 日 受理 1985年 1 月14日
} 


\section{Iはじめに}

慢性硬膜下血腫は兴神経外科領域においてはありふれた 疾患であり，診断はCT scanによりきわわて谷易となっ た。また，治療は穿孔術による血腫洗條が主であり，猃 断，治療についての問題点は少ない。しかしその成因，血 腫堌大の機序となるといまだに不明の点が多い，近年, 慢 性硬膜下血腫の発生過程2,11,16,17,24,26,30,33,35)，また術後の血 尰消失の過程7,18,28: をCT scanにより释時的に観察した報 告が多数みられるようになった。しかし，慢性硬膜下血腫 が完成後どの上うに変化していくかを，手術をせずに保存 的に治㞠し，CT scanに上り経時的に䂓察した報告はきわ めて少ない133. 我々は1968年以降, 慢性硬膜下血腫に対し $て$ mannitolに上る浸透厈療法を試み，その有效性につい て報告し22)，また種々の stageに扔外る血腫被膜の電顕槽 本の所見加血腫增大の機序を考察し，本療法の有效性の

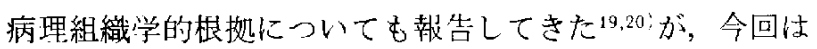
本燎法を行った症例の CT 像の経時的变化を観察し, 特に 造影剂静注 4 時間後の delayed contrast enhancement CT (以下 delayed CT 之略す)所見について與味ある知見を得
たので, 慢性硬膜下血睡の増大, 縮小の機忬について考察 を加え報告する。

\section{II 対象および方法}

\section{1. 対象 (Table 1)}

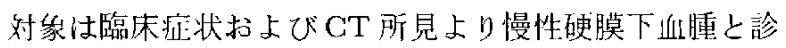
断された20例であり，男性19例，众性 1 例で，年齢は20 71 才, 平均51才である。外傷の既往は19例に認められ，外 傷から第 1 回 CT 撮影までは23 120日, 平均67.7日, 聇 状発現より第 1 回 CT 撮影までは $0 \sim 57$ 日, 平均 $18.3 \mathrm{Hで}$ ある.これらの痛例に対して $20 \%$ mannitol $1,000 \mathrm{~m} / /$ day, 2 週間連日投与に上る浸透压療法を行い, 臨床症状の推移 を観察するとともに，以ドの久ジュールに従ってCT scanにより血腫の消長を追跡した.

\section{CT scan による追跡}

Monnitol 治㞠開始前, 開始 1 週後, 2 週後!治療釉了 時), 終厂 1 週後, 2 週後, 1 力月後, 2 力月後, 佂例に よっては血腫の消失する 4 ・5 カ月後までCT scankよ る追跡を行った。 CT scan は plain CT, $60 \%$ meglumine iothalamate (Conray) $100 \mathrm{ml}$ 急速点淌静注直後の通常の

Table 1 Summary of 20 cases treated by nonsurgical osmotherapy

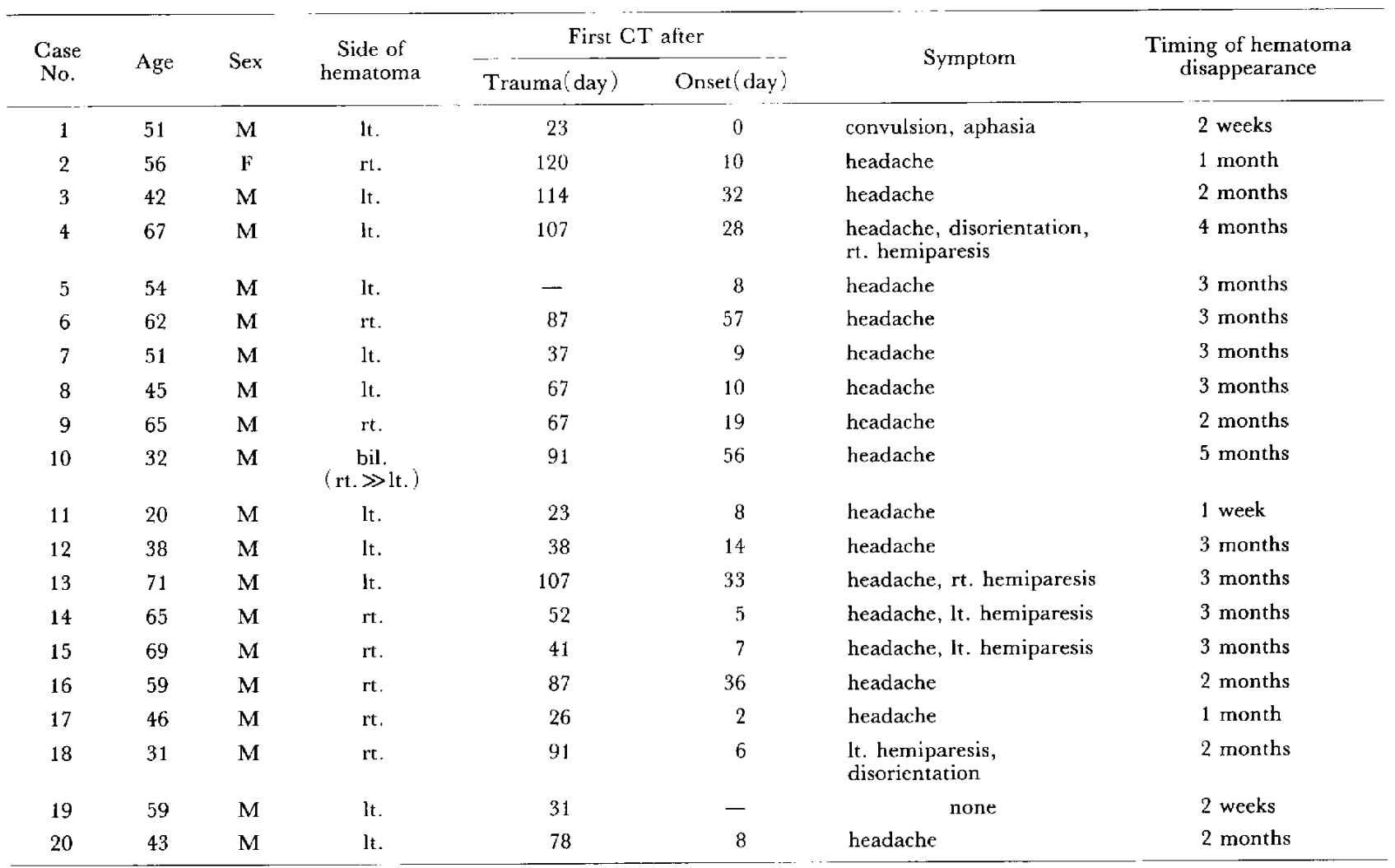

CT indicates computed tomography. 
contrast enhancement CT, おちよび点滴静注終了 4 時間後 の delayed CT 施行した. CT は鳥津 SCT-100N おょび 日立CT-HF老使用L, window level 40, window width 100 の条件で観察打よび写真撮影した。

\section{(1) Plain CT 像における観察}

血腫サイズ, midline shift の経時的推移：Orbitomeatal lineに平行なスライス酒で血腫の最大厚さを計測し，撮影 像の穛小率で除した值を丘腰サイズとした，Midline shift は同样に第三脸室の最大の体位で表した。

血腫 density の経時的推移：Plain CTに打汁万慢件硬 膜下血腫像は全体が homogeneousなものと一部が周国に 比して high density 示すむのがあり，前者の埸合は折腫 のもっとも厚いスライスで所蕾の上，中，下の 3 点に 1 力 所 9〜31ピクセルの関心領域を没定してCT值を測定し， 後者の場命は low density 部およびhigh density 部よりそ 九ぞれ2点ずっ同样に関心領域を設定してCT 值を測定 し、いずれも平均值をとって血䤚のCT值(density)とし
た。

\section{(2) Contrast enhancement CT 像における覾察}

Plain CT と同一スライス面において血腫腔，血䤚被膜 および詰囲脸約織に注日し，増强效果の有無注肉腿的にの み判定した。

\section{(3) Delayed CT 像における観察}

3 例に扝いて造影剂静注後 1 時間ごとに 6 時間まで CT scan を施行し，选影剂增強効果を雄察したところ，静注 直侵には汪とんど增强效果の認められなかった血埂腔にお いて 1,2，3時間上肉眼的に明らかな density の上界が観察 され，4時間以後ははぼ同样であった(Fig.1)。この絬果 より delayed CTの撮影 timing 法造影剤静注 4 時間後と し，血腄腔の densityの変化に注甘した。 Delayed CTに おける血腫 density の測定は plain CTにおける血腫 densityの测定と同様に行い, delayed CTのCT值から同 - 又 ライスの plain CTのCT值を減じたもの的 Noと し，これを増強效果とした。

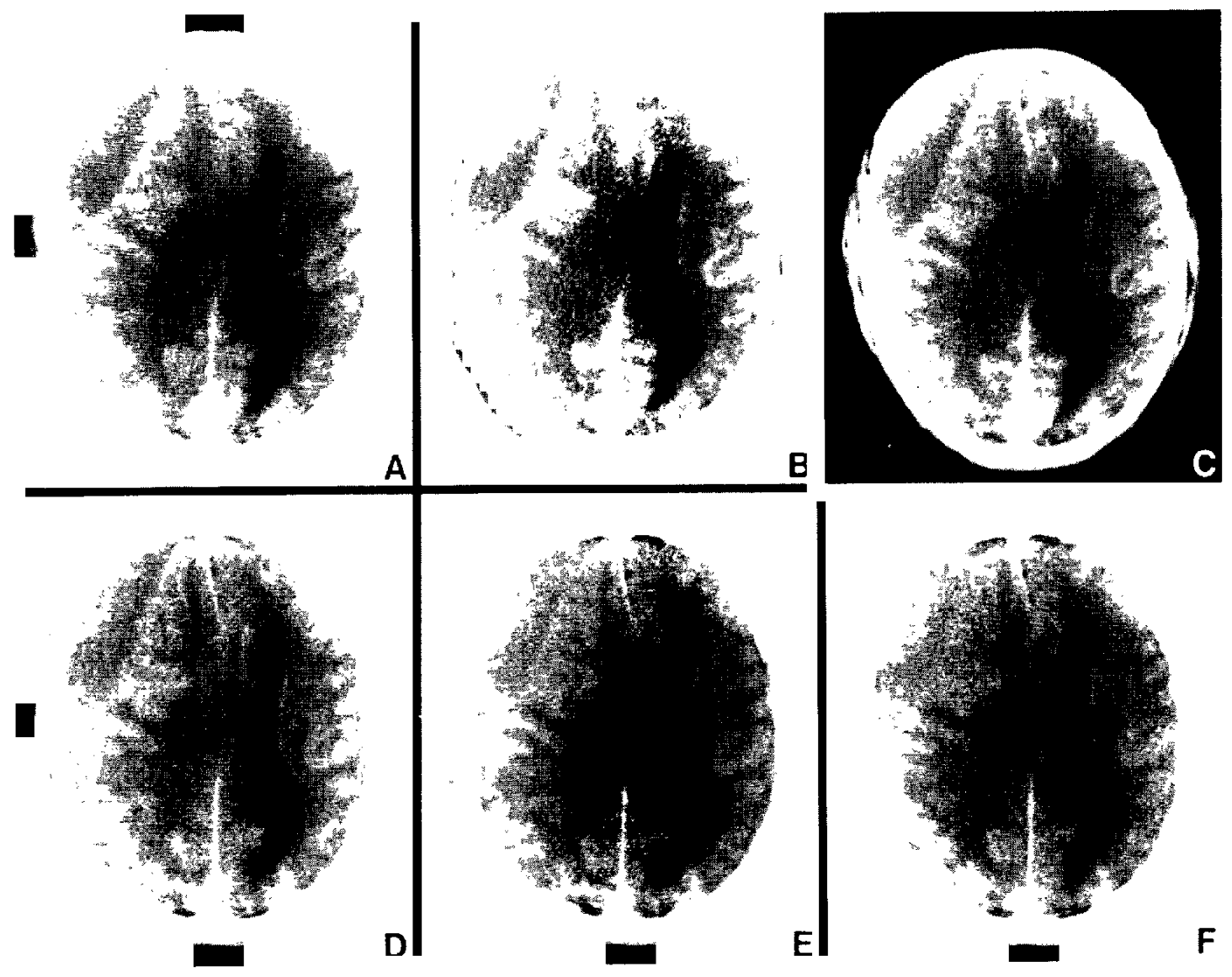

Fig. 1 Delayed contrast enhancement computed tomography (CT) scans. A: Plain, B: Contrast enhancement, C: 1-hour-delayed, D: 2hour-delaycd, E: 3-hour-delayed, F: 4-hour-delayed CT. 
以上の plain, contrast enhancement, delayed CT 所見につ いて前述のスケジュールに則り， mannitol とよる浸唀圧 蟟法を中心に経時的に観察した。

\section{III 結 果}

\section{Plain CT 所見}

血腫サイズについては，汇とどの龇例で mannitol 投 与終了 1 週後頃上り血缰の急速な縮小が㝃め放，投与終 了 2 週後までに血腫の消失したものが 3 例あり，投与終了 2 力月後までには計10例で血腫が消失したが，地の10例で はまだ血腫の残存が認められた(Fig. 2). Midline shift

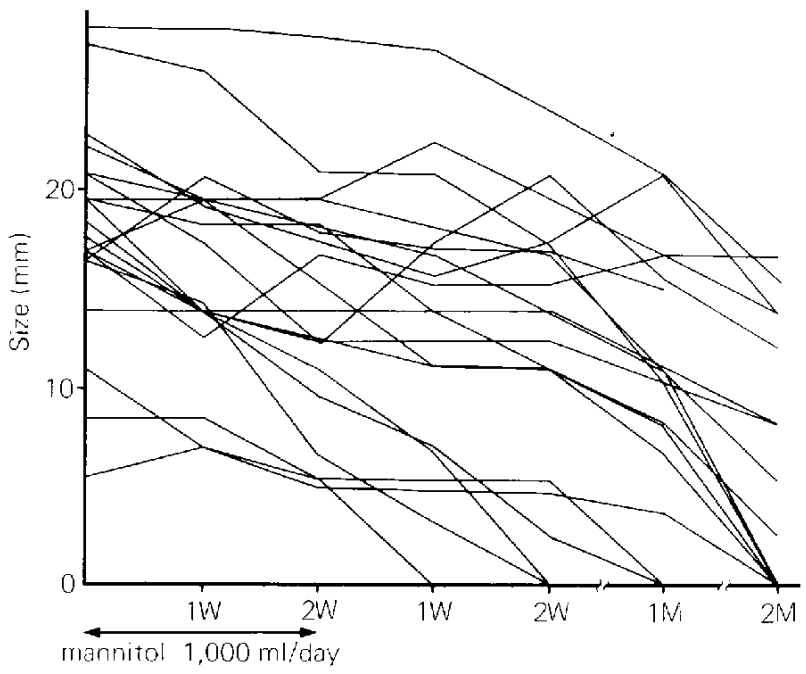

Fig. 2 Sequential changes of the hematoma size. W indicates week; M, month.

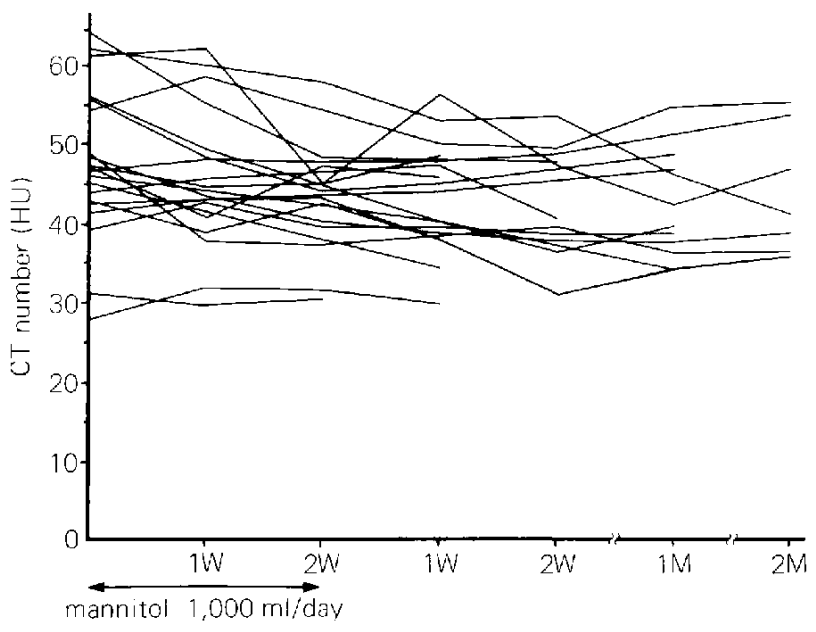

Fig. 3 Sequential changes of the hematoma density.
血腫サイズとほぼ同様の傾向をふし，治撩前平场8 $8.00 \pm$ $5.41 \mathrm{~mm}$, 治㞠終厂時 $5.51 \pm 4.73 \mathrm{~mm}, 1$ 力月徭 $1.95 \pm 2.55$ $\mathrm{mm}, 2$ 力月後 $1.43 \pm 2.48 \mathrm{~mm}$ と娍少していた。一方，血 腫 density については mannitol 投与期間中 一時 densityの 上曻をみたすのが 9 例あったが，そのうち症状の悪化した ものは 1 例のみであり， densityの低トまたは不变を示し た11例でも症状悪化のみられたものが 3 例あった。しかし， mannitol 投与終了後海臨床痁状は消失し，血脾の縮小上 ともに血腫 density は徐々に低下した(Fig. 3)。

\section{Contrast enhancement CT 所見}

慢性硬膜下血腫に扔ける contrast enhancement CT 所見 は以下の 2 型に分類された(Fig.4)。すなわち，血腫直卜 の脳表で脳溝に沿ってリボン状の增強効果 (cortical enhancement)の認められるもの(ただし，Fig. 4 leftでは対 側脳表にも增強効果が羿められる)，および血腫直ドで血 腫内面に沿って線状の増强効果(linear enhancement)の認 められるものである。沿療前には20例中16例(80\%)に造影 版増强効果が認めら机たが，そのうち cortical enhancement 14 例， linear enhancement 2 例であった。しか し， mannitol 投与終了时には20例中13例 $(65 \%)$ に増強㸚 果が認められ，そのうち cortical enhancement 9 例, linear enhancement 4 例となり，1カ月後では血腫の残存した 15 例中 9 例 $(60 \%)$ に增強効果架認められ，cortical enhancement 1 例, linear enhancement 8 例, 2 力月後では10例中 7 例 $(70 \%)$ に增強効果が認的られ，cortical enhancement は1例もなく、すべて linear enhancement となっていた。

\section{Delayed CT 所見}

Delayed CT 像にお汁る增強効果恃血䭪腔の density 上昇として観察された。治療前 $\Delta \mathrm{CT}$ No. は0.6〜11.7, 平 均5.31土3.07であったものが， 1 週徯 $0 \sim 9.1$ ，平均4.60土

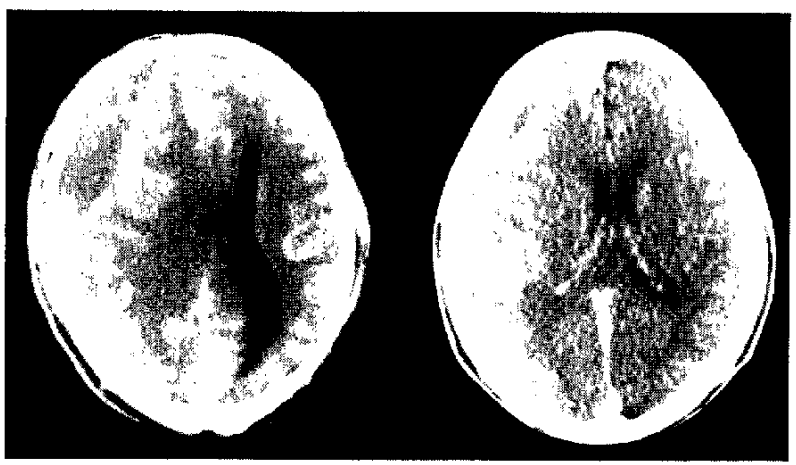

Fig. 4 Two types of contrast enhancement in cases of chronic subdural hematoma. lefi: Cortical (ribbon-like) enhancement is shown in cortex. right: Linear enhancement is shown beneath the hematoma. 


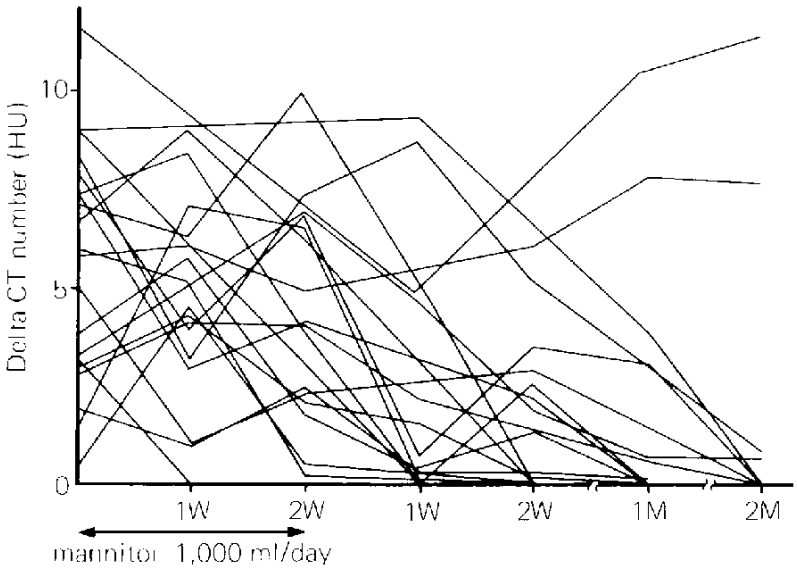

Fig. 5 Sequential changes of the delayed contrast enhancement effect.

2.50，2週媵 $0 \sim 10.0$ ，怗均3.92士2.52と娍少し，さらに mannitol 投与終了 1 䓢後で泣 $0 \sim 9.4$, 平均 $2.59 \pm 3.03,2$ 週後 $0 \sim 7.9$, 平地1 $1.75 \pm 1.97$, 1 力月後 $0 \sim 10.6$, 平均

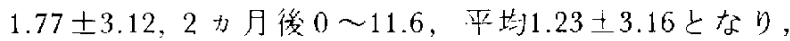
mannitol 憭法㧍よびその㣪の时間経過とともに増強効果 は低下していく傾向を認めた(Fig，5)。

一方，臨休経過，血腫サイズの消長と delayed CT 所見 上の関係をみると，怔例は delayed CTに拉ける増強効果 の経時的变化により次の 3 群に分類された。すなわち，第 I群：delayed CTに抢汁万增强効果が治撩とともに低下 していくもの(〈症例 1 3, 7 9,17，18，20〉)で，これらで

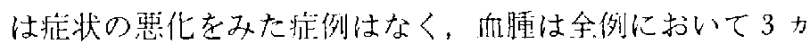
月以内(平均1.8力月)に消失していた。第而样：治療中

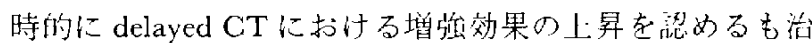

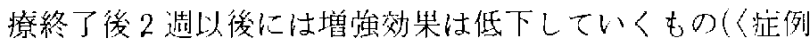
5, 6, 11 16，19〉)で，こ机らでは 4 例に治療期間中一時拉

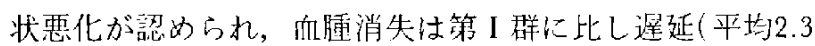

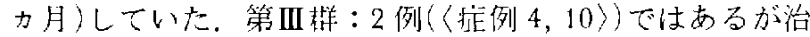
療終了後も長期にわたり delayed CTに打汁る增強効果が 持絖し，牦埂消失までに〈症例 4 〉では 4 力，〈症例10〉で は 5 力月要しした。な抬撩終了時には20例全例で隐决 症状はほぼ消失し，2力月後の時点で拝状の再発をきたし た症例はなかった。

以下，代表的症例老呈示寸る。

<症例17>46才，男性

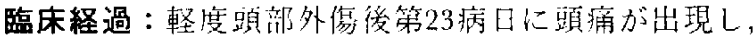
CT scan $の$ 結果慢性硬膜下血睡と診断され，当科に結介入 院した。入院時意識清明で頭捅を訴えるも糜㾯はなく，神 経学的に特に翼常は㤠好ながた。だちに20\% man-
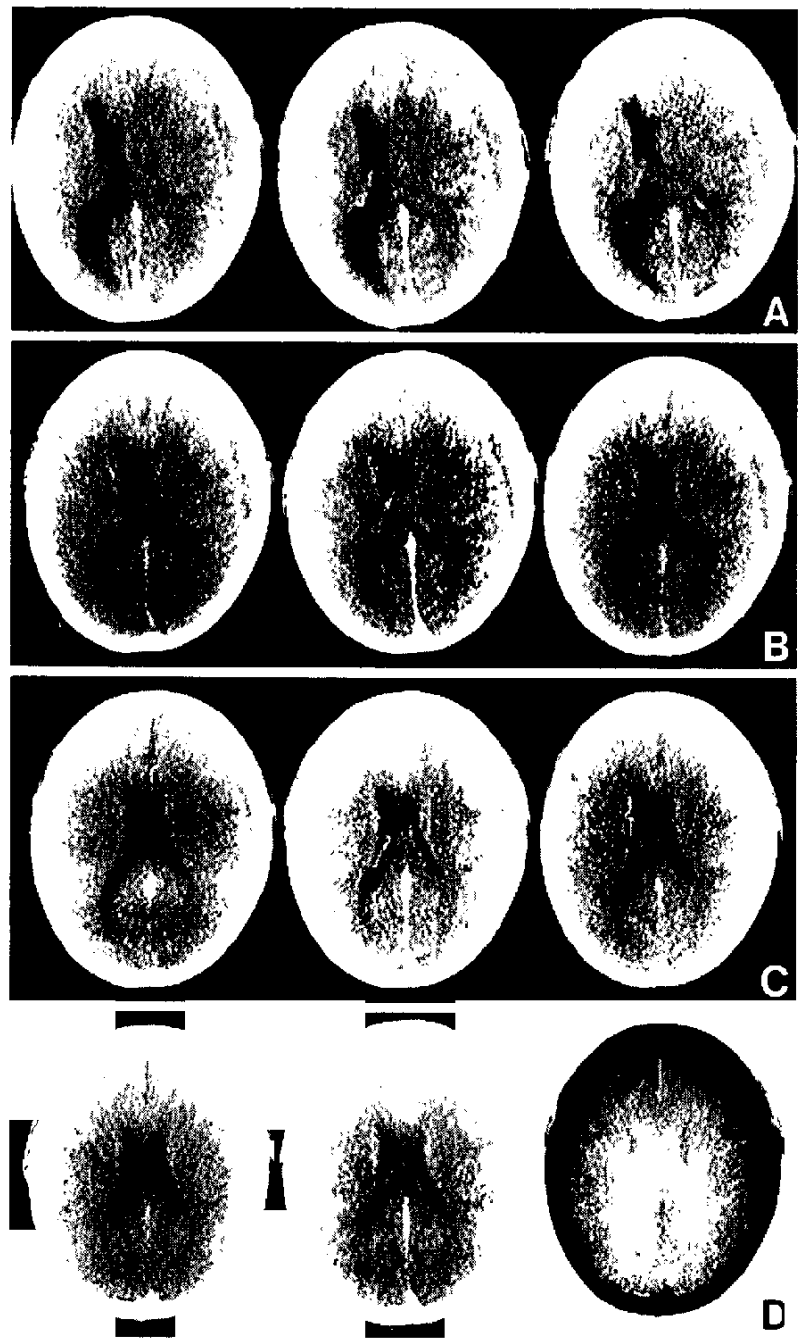

Fig. 6 Sequential changes in CT scans of Case 17. A: Pretreatment, B: Just after treatment, C: 2 weeks after treatment, D: 1 month after treatment. In each quadrant the image on the left is the plain CT; the image in the middle is the contrast enhancement CT; and the image on the right is the delaycd contrast enhancement CT.

nitol $1,000 \mathrm{~m} / /$ day, 2 邀咸連日投与による浸透圧療法を施 行し，頭痛は治療閉始 7 口日にはほぼ消失した。

経時的 CT 所見(Fig, 6)：治療開始前には plain CT で石 半球脳表に厚さ最大 $17 \mathrm{~mm} の$ homogeneousな isodensity (CT值47.3) 示す血腫が熟めら机，midline shift は16.8 mmであった. Contrast enhancement CT では脳表の cortical enhancement が涊められるむ血腫腔内の CT 值の上昇 は認めら礼ずままた delayed CTでも肉眼的な血腫整の堌 强効果はほとんどみられず，計测上の增强効果， $\Delta \mathrm{CT}$ No. 沬わずかに3.0であった。. Monnitol 2 週間投与終了時 

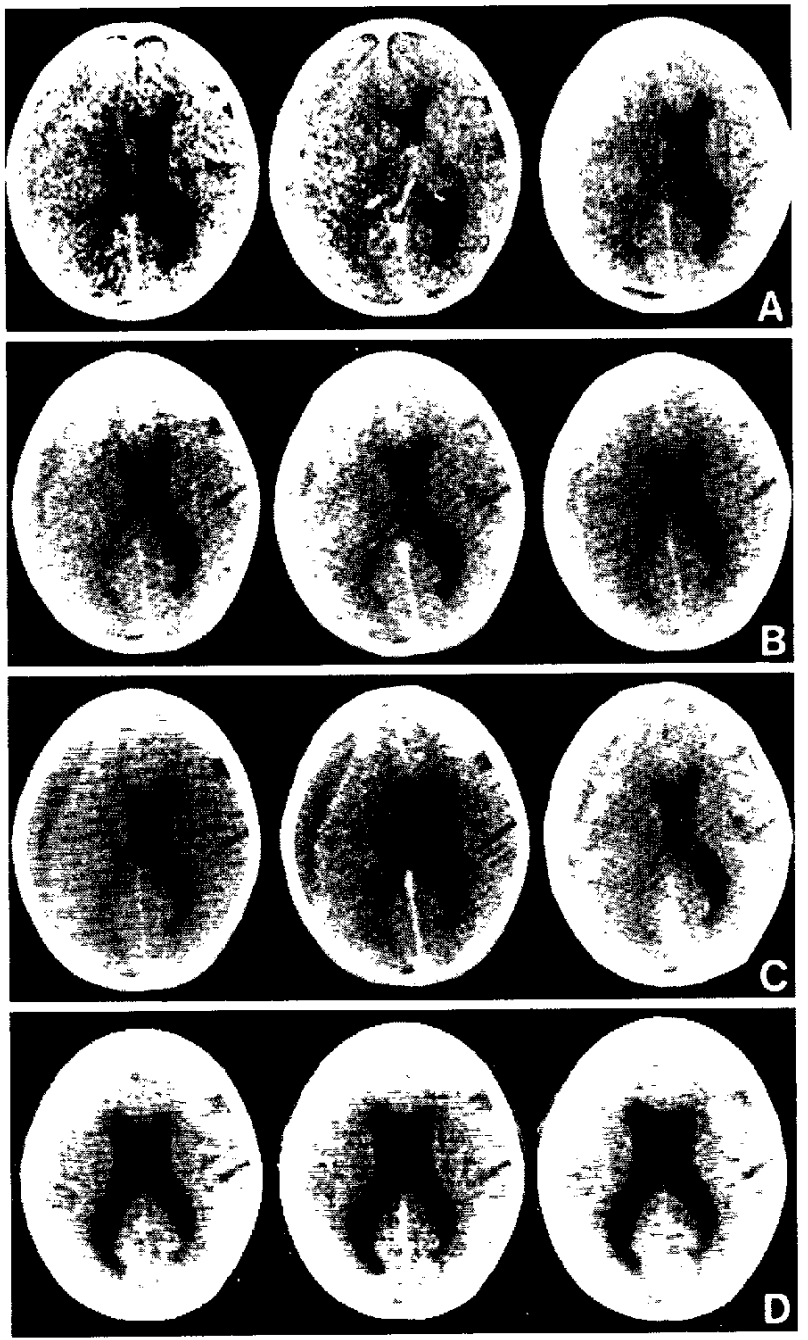

Fig. 7 Sequential changes in CT scans of Case 4. A: Pretreatment, B: Just after treatment, C: 1 month after treatment, D: 4 months after treatment. In each quadrant the image on the left is the plain CT; the image in the middle is the contrast enhancement $\mathrm{Cl}^{\prime}$; and the image on the right is the delayed contrast enhancement CT.

の plain CT では血腫の厚さは最大 $10 \mathrm{~mm}$, midline shift も $8.4 \mathrm{~mm}$ と減少したが血腫の density は変わらず，また contrast enhancement CT では前回に比べて cortical enhancement が減少し， delayed CTでは前回同様ほとんど堌强効 果を認めなかった。 Mannitol 投与終了から 2 週得では血 䏦はさらに樎小し， midline shift は消失した。 Contrast enhancement CTでは血腫内面の linear enhancement が瀵 察されたが delayed CT ではもはや血腫腔の增強効果は認 められず，mannitol 投与終了から 1 力月後，血腄は完全 に消失した。
<症例 4>67才，男性

臨床経過：意喑障告を伴わぬ頭部外傷で近医に10日間入 院したが，その传拝状なく働いていた。ここが受傷79日 後より頭痛が出現し，しだいに友片麻痺，軽度意諳障害も 加わる上うになったため，当科に紹介入院した，入院時意 職レぶルは 3-3-9 度方式で2，独歩叮能であるがやや右足 を引きずる程度の片麻瘦を認め，頭痛を挀えた。ただちに 浸透压療法を開始したとこ万 3 日目に頭痛は消失し，7日 目に澺識清明となって在片麻瘏もほ注消失した。

経時的 CT 所見 (Fig. 7) : 治憭開始前の plain CTにて布 半球脳表に厚さ最大 $23 \mathrm{~mm} の$ 血腫が認めら九，これは CT 值46で肉眼的には isodensity 呈し， midline sift は 10.5 mmであった。 Contrast enhancenent CT では脳表がわず かに增強されるのみであったが， dclayed CTでは血腫全 体が立沉か力著明に增強され， $\Delta \mathrm{CT}$ No. 注11.7であった。 Mannitol 投与終了時には血腫 density は低下し(CT值 41.7)，向腫サイズ(厚さ $16 \mathrm{~mm})$, midline $\operatorname{shift}(5.3 \mathrm{~mm})$ も 減少した。また，contrast enhancement CTでは血腫内側 の増強効果がほぼ消失していたが， delayed CT では前回 と㓋なったパターンを示し，血畽外側が增強されるように なり， $\Delta \mathrm{CT}$ No.は4.9と低下した。. Mannitol 投与終了 1 力 月後には血腫 density はさらに低下した(CT 但37.3)が血 腫サイズはほぼ不変であり， contrast cnhancement CTで は血腫內僛に linear enhancement が認められるようになっ た。 Delayed CT では前回同様血腫外側が増強され， $\mathrm{CCT}$ No. は10.2と再上昇示していた。 2 力月後， 3 力月後も 血喠は縮小しているものの縮小速度が遲く, delayed CT に打ける增強効果も1力月传とほぼ不变であった。そして 4 力月後, 血腫はやっと消失した。

\section{IV 考察}

慢性硬膜下血腫の成因については古くはVirchow ${ }^{299} の$ pachymeningitis hemorrhagica interna 説, Trotter ${ }^{271}$ の外傷 説があり，また增大機序には反復出机説や浸透圧説㤩があ るが，血腄内および血腫外膜の局所線溶活性九進により持 続的・断続的出血が生じ血睡が增大するという説5,6,8,12,34 もある.1932年，Gardner ${ }^{3}$ の提唱した浸透压説は，1970

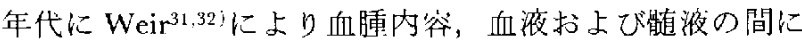
は浸透圧の差がないと報告されてはいるものの，血腫の膠

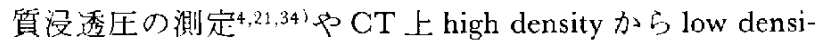
tyとなって血腫の增大寸る症例もみられること年,30,35)など からなおきわぬて有力であり，我々も慢性硬膜卜血腫の 20\% mannitolによる浸透压寮法を開発し, 良好な治療成 績を報告している22.23!．ところで，慢性硬膜下血腫は本来 自然治愈傾向を持つものもあり，本シリーズの症例もこの 
ような怔例ではないかとの疑問もあるが， mannitol 投与 により速やかに症状の改善を涩めており，臨床的に浸透圧 療法は有効であったと言える。

今回我々の検討した20例の浸透圧療法前後の臨休拝状扔 上びCT 所見の経時的変化をみると, 症状恃本撩法終了洔 には全例で消失していたが，血腫サイズ汢本療法終了1迴 後あたりから著朋に維小していた。史た，血腫 density は 受傷および泟状発現から CT 施行までの期間ならびに泟状 の軽重には関連なく，本療法の進行および時間経過ととも にほとんどの拉例で低トしていた。しかし，なかには本療 法中 densityが一時上䄯するものもあった。一力, contrast enhancement CT では洎腫挖自体が増强された症例は 諗められず，血腫內側の脳表にリボン状の堌强扮果(cortical enhancement)あるいは血腫内膜に沿った線状の增強 効果( linear enhancement)が瑟められ，このうち前者の变 化が近腫の消长之関保が深かった。すなわち，治療淤には $70 \% の$ 拝例に cortical enhancement が認められたが，時間 経過とともに cortical enhancement 示す拝例は減少し， 2 力月後に血睡の残存していた10例では 1 例にも認められ なかった。こ机は，田口ら 25$\rangle$ 報告のごとく cortical enhancement が血腫点に相関するような印象を与える。し かし，本シリーズの〈症例11〉(20才男性例)では厚さ最大 $8.4 \mathrm{~mm}$ と比較的小さな血腫であるにもかかわらず著明な cortical enhancement が怒如られたのに対し，〈症例 4 〉(67 才男性例，前述）では淖さ最大 $23 \mathrm{~mm}$ とかなり大きな血腫 であるにもかかわらず cortical enhancement は著明ではな いすななわ，我々は cortical enhancement は血腫量と脳 の容積の和に相関し，血腄に上る脳表の居迫や脳循環代謝 に対する影響の程度在反映しているのではないかと考えて いる，一方，血腫の緶小上ともに増加した linear enhancement はあたかも仙腫内膜が増強されているがごとさ像を 呈していたが，我々の経験ではこの時期の血腰内膜には增 強効果を示すほどの血管の存在はなく，厚さも持ってはい ないので疑問であり，今後の换討を要するところである。

慢性硬膜下血腄に扝ける delayed contrast enhancement

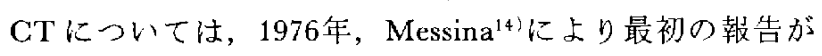
なされて以来，数編の報告が散見される1,7.15!。しかし， そのほとんどが isodense subdural hematomaの診断法とし ての報告であり，臨床症状と delayed CT 所見との関連に

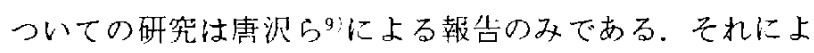
ると， delayed CTにおけるCT值の上暑，低下は造影剤 がなんらかの機序で血腫腔内に流入, 流出していることを 示しており，これは慢性硬膜下血腰内一の血液，血漿成分 の流入・流出垷象が存在することを示唆し，血腫の消舆に 梁く関与していると推察している。ささらに彼ら苚打上び
Messina ${ }^{14}$ 注, 造影剤静注後 $3 \sim 6$ 時間に血腫内容液中の 造影剂濃度を測定し，静脈血中の濃度と比較したところ， 血䏦内容液中では静脈血中の10５0倍も高濃度であったと 報告しており，これは造影郕が政中から血腫腔内に移行， 蓄積したこと在意味し， delayed CTに括ける增強效果を 裏付けるむのである。

一方，我々のシリーズにおける delayed CT 所見では， 増强効果が強くかつ持続する症例任ど血腫消失が羊延して いた，教室の佐藤ら ${ }^{19,20}$ 注， mannitolに上る浸唀珐㞠法に より治㞠した種々の stageの慢性硬膜ド秃腫外膜の血管を 電顕にて観察し，浸透圧療法施行前の活動期にある拝例で は血管内皮細胞の偽突起形成，fenestration が多くみられ， 血管透過性が異常に六進している所見が得られたのに対 し，浸透厅療法老施行し治瘾機転にある症例では血管内皮 細胞の偽突起形成江減少, fenestration 法消失し, 逆化物 質の能動翰送に関与する pinocytotic vesicle が增加し，血 管透過性が改善され，さらに膠原線維の増生もみられ，血 管は正常化することを示した，今回の我々の研究や従来の 報告から delayed CT に扔ける增強効果の強いものは血腫 腔八の造影剂の漏出が大きいものと考えられ，これは向腫 外膜の sinusoidal channel layer での血管透過性が充進して いるもので活動期にある慢性硬膜卜゙血腫と考えられ、一方 增强効果の低下したものは血管透過性の低下しているもの であり，才でに治療吸収機転に入ったものとも考えられ た。すなわち、この delayed CTによって慢性硬膜下血腫 が増大・活動期にあるものか，あるいは治㹱の方向に向か っているものかが予測可能であると考えられた。

\section{$\mathrm{V}$ ま め}

$20 \%$ mannitol 静注 $1,000 \mathrm{ml} /$ day, 2 週間連H投与による 浸透圧療法を行った慢件硬膜下血腫20例を用い，本療法施 行前から血腫消失までの経過を臨床症状扔よびCT scan にて追跡し，以下の結果を得た。

1. 臨床症状法全例で本撩法終〕時には消失していた が，血腫注本療法終厂 1 週後から急速に維小していくもの が多かった。生た，血腫 densityも本療法施行後の時間経 過とともに低下していたか，本㞠法施行中一時的にdensityの上昇した症例もみられた。

2. Contrast enhancement CT では全経過を通して血腫 腔が增強された症例はなく，本療法施行前には欰腫内側の 脳表がリボン状に增強される cortical enhancement が70\% の症例で観察された。しかし，本療法施行啳は血腫の緶小 とともにその頻度は低下し，本療法終了２力月後にはまっ たく認められなかった。

3. Delayed CTにおける増强效果は血腫腔の density 
の上并として観察され，その程度は本撩法施行後の血腫樎 小速度に相関し，增强効果が強くかつ持続する症例ほど血

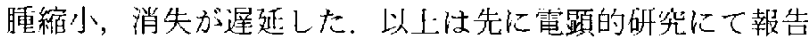
したごとく，慢性硬膜下血腫の活動期，增大期ほじ血腫外 膜の sinusoidal channel layer での血管透過性が人であり， 活動期を過ぎて治療傾向になると血管透過性が正常化して いくことと一致しており， delayed CTによって本血腫の 活動能を判定できるのではないかと考えられた。

\section{文献}

1) Amendola MA, Ostrum BJ: Diagnosis of isodense subdural hematomas by computed tomography. Amer J Roentgen 129: 693697,1977

2）藤岡正尊，松角康产，賀来素之，桜閤信義，野中信二，二

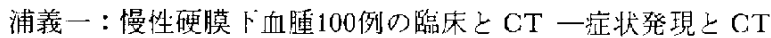
沂見における血腫発育過程—. Neurol Med Chir (Tokyo) 21: 1153-1160, 1981

3) Gardner WJ: 'Traumatic subdural hematoma with particular reference to the latent interval. Arch Neurol Psychiatry 27: 847-858, 1932

4) Gjerris F, Sorensen SG: Colloid osmotic and hydrostatic pressures in chronic subdural hematomas. Acta Neurochir (Wien) 54: 53-60, 1980

5) Ito H, Komai $\mathrm{T}$, Yamamoto S: Fibrin and fibrinogen degradation products in chronic subdural hematoma. Neurol Med Chir (Tokyo) 15 [Part I]: 51-55, 1975

6) Ito H, Komaj T, Yamamoto S: Fibrinolytic enzyme in the lining walls of chronic subdural hematoma. $J$ Neurosurg 48: 197-200, 1978

7) 作藤治英，下地 隆，安所厚子，山嶋势盛，川本信二郎： 慢性:硬膜下血腫の CI 像の推移と治療方針一上くに術闹術後 のCT像について一, 神経外傷 3: 187-192, 1981

8) Ito H, Yamamoto S, Komai T, Mizukoshi H: Role of local hyperfibrinolysis in the etiology of chronic subdural hematoma. $J$ Neurosurg 45: 26-31, 1976

9）店沈秀治，大呈 该，上野純可，渡辺三郎，三壁敏䧸，金 玧，副田 伸：外侮性硬膜下水腫㧍上び慢性硬膜下血腫にお ける delayed contrast-enhanced CT $\sigma$ 所見について. CT 矿究 4: $565-569,1982$

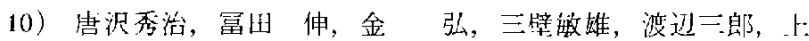
野純司，大屋 滋：慢性硬膜卜血腫の成因に関する考察一血 蕾腔内一の造影剂の移行について一. (全) 第6 回脳神経 CT 研究全抄録， $1983,92 \mathrm{pp}$

11）小泉英任，深町 彰，莙尾哲夫，田崳健，永関慶重，矢 内由美：成人例外傷性硬膜下本腫一慢性硬膜下血腫と口関連 性について一. Neurol Med Chir (Tokyo) 21:397-406, 1981

12）駒井杜詩夫，伊藤治英，山嶋哲盛，山本信二郎：慢性硬膜 下而腫の成因一步所的線溶活性九進の観点加ら一. Neurol Med Chir (Tokyo) 17 [Part II]: 499-505, 1977

13) Lusins J, Nakagawa H, Bender MB: Computer assisted tomography of unoperated subdural hematoma: Short and longterm follow-up. J Compul Assist Tomogr 2: 460-466, 1978

14) Messina AV: Computed tomography: Contrast media within subdural hematomas. A preliminary report. Radiology 119: 725726,1976

15）御供政紀：外傷性疾患. 高橋晆 正(編)，神释疾患のコンピ エーター断層掫影。東京, 南江堂, 1979,403 pp

16）宮崎紳一郎，太森英俊，金沢泰雄，宗像克治，福撚廣己， 镰田健一：慢性硬膜下血腫の成因に対寸百考察一経時的 CT scan に上召観察力ら--. Neurol Med Chir (Tokyo) 20: 875-881, 1980

17）内藤獢皓, 㓩川基継, 森本垫也, 榊 寿石, 分掛龍夫, 宮 本誠司，京井喜久男，内海生二郎：慢性硬膜下血腫の臨床像 の推移とCT 所見. Neurol Med Chir (Tokyo) 21: 961-968, 1981

18）西嶌美智春，堀汇幸男，中田潤一，岡信太，遠藤俊郎， 高久 光：慢性硬膜下血腫の術後血腫腔の消迟速度について の㛟討一释時的 CT 所兄の観察䘮中心に一。脳神外科 11: $813-819,1983$

19）佐藤 壮，鈶木二郎：慢性硬膜卜血腫の非観血的療法一第 2 報 血腫被膜の電湿的観察—. 脳と神 25:557-563,1973

20) Sato S, Suzuki J: Ultrastructural observations of the capsule of chronic subdural hematoma in various clinical stages. $J$ Neurosurg 43: $569-578,1975$

21）下地 隆，木朴誠，前用優，山鸠哲盛，伊滕治英，山 本信一郎：慢性硬膜卜血腫に打江膠質浸透厈の意義につい 下. 神経外傷 $5: 275,1983$

22) Suzuki J, Takaku A: Nonsurgical treatment of chronic subdural hematoma. I Neurosurg 33: 548-553, 1970

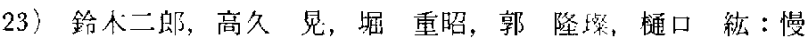
件硬膜下组腫の非観血的療法一第1報一，脳と神 20：721731,1968

24）田山苊维，中村紀夫，佐藤 醇，長谷川芳男：慢性硬膜下 血腫の発生過程について一CTに上る経時的観察加ら一. Neurol Med Chir (Tokyo) 22: 276-282, 1982

25）田口若雄，佐藤 醇，牧田亘俊，林茂利，中村紀夫：慢 性硬膜下血腫に接する兴の enhancement について. CT 研究 3: $697-702,1981$

26）高橋義舁，佐耗宏之，井上慶俊，武田聡，大川原修二： 慢性硬膜下血腫のCT的検討(第 1 叝) 一その発生予测一。 Neurol Med Chir (Tokyo) 21: 485-490, 1981

27) Trotter $W$ : Chronic subdural hemorrhage of traumatic origin and its relation to pachymeningitis haemorrhagica interna. Brit $J$ Surg 2: 271-291, 1914

28) Victoratos GG, Bligh AS: A more systematic management of subdural hernatoma with the aid of CT scan. Surg Neurol 15: 158160,1981

29) Virchow R: Das Haematom der Dura Mater. Verhandlungen der Physikalisch-Medizinischen Gesellschaft Würzburg 7: 134-142, 1857

30) 渡讱 卓, 渡迅高志, 作々木富守, 村用貞菏, 山田久： 急性硬膜下䍀腫上り発牛した慢性础膜下血尰一外傷性硬膜下 水腫より続発する型との比較に打いて一，神経外傷 3: 159 164,1981 
31) Weir B: The osmorality of subdural hematoma fluid. J Neurosurg 34: 528-533, 1971

32) Weir B: Oncotic pressure of subdural fluid. J Neurosurg 53:512515,1980

33) 山田久, 渡辺卓, 渡辺高志, 佐々木富男, 村田貞吉： 外傢性硬膜下水腫40例の释過観察の分析一慢性硬膜下血腫の 発生㗻程一. Neurol Med Chir (Tokyo) 20: 1229-1238, 1980

34）山本信二郎，伊藤治英，水腰英隆，吉出早苗：慢性硬膜下 血腫における血腫被膜からの出血の意義. 脳神外科 2：239-
242,1974

35）吉益倫夫，田村 茪，若井 晋，吉本智信：硬膜下出血上 り慢性硬膜下血腫へ一CTよりみた慢性硬膜卜血腫の発生過 程一. 脳神外科 9: 1025-1031, 1981

〔別刷請求先：干980 仙台市星陵町1-1, 東北大学脳研脳神経外 科, 金城利㦄] 